\title{
The effect of structural enrichment in hatchery tanks on the morphology of two neotropical fish species
}

\author{
Sarah de Oliveira Saraiva ${ }^{1}$ and Paulo Santos Pompeu ${ }^{2}$
}

Reared fish differ from wild fish in several aspects, including morphology, because they are adapted to captive conditions that are totally different from natural conditions. To minimize the influence of the hatchery environment on the morphology of fish, the use of environmental enrichment through the incorporation of natural designs in captivity, has been proposed. In the present study, we performed the physical structuring of fish farming tanks to verify the enrichment effect on the morphology of two species of neotropical fishes: Prochilodus lineatus and Brycon orbignyanus. Each species was subjected to four different treatments over two months: tanks with submersed logs, with artificial aquatic plants, with both structures and without any structure. Results showed that the structural enrichment had a strong effect on the morphology of the cultured fish, which varied with each species analyzed and with the type of structural complexity added to the tanks. There was an increase of morphological variability in the population of P. lineatus and an increase of the average length in the population of $B$. orbignyanus. This shows that the environmental enrichment is capable to induce morphological differentiation through phenotypic plasticity, probably generating phenotypes more adapted to exploiting a complex environment.

Peixes cultivados diferem de peixes selvagens em vários aspectos, incluindo morfologia, pois são adaptados às condições de cativeiro, que são totalmente diferentes das condições naturais. Para minimizar a influência do meio de cultivo sobre a morfologia dos peixes, o enriquecimento ambiental, através da incorporação de 'designs' naturais em cativeiro, tem sido proposto. No presente estudo, foi realizada a estruturação física de tanques de piscicultura para verificar o efeito deste tipo de enriquecimento ambiental sobre a morfologia de duas espécies de peixes neotropicais: Prochilodus lineatus e Brycon orbignyanus. Cada espécie foi submetida ao longo de dois meses a quatro diferentes tratamentos: tanque com troncos submersos, tanque com plantas aquáticas artificiais, tanque com ambas as estruturas e tanque sem qualquer estrutura. Os resultados demonstraram que o enriquecimento estrutural teve forte efeito sobre a morfologia dos peixes cultivados, o que variou de acordo com a espécie analisada e com o tipo de complexidade estrutural adicionada aos tanques. Houve aumento da variabilidade morfológica na população de $P$. lineatus e aumento do comprimento médio na população de $B$. orbignyanus. Isto mostra que o enriquecimento do ambiente de cultivo é capaz de induzir a diferenciação morfológica através de plasticidade fenotípica, provavelmente gerando fenótipos mais adaptados à exploração de um ambiente complexo.

Key words: Artificial macrophytes, Brycon orbignyanus, Phenotypic plasticity, Prochilodus lineatus, Submersed logs.

\section{Introduction}

Fish stocking is a method that has been historically used to mitigate impacts caused by dams. However, the efficiency of stocking as a management measure has never been confirmed in Brazil (Agostinho et al., 2007). This can be the result of the low survival rates of released fish, because they are adapted to the hatchery environment (Maynard et al., 1994), which is quite homogeneous and completely disparate from the natural environment (Pakkasmaa et al., 1998).

Reared fish are different from wild fish in relation to aspects such as behavior (Berejikian et al., 2001; Brown et al., 2003;
Braithwaite \& Salvanes, 2005) and morphology (Taylor, 1986; Swain et al., 1991; Flemming et al., 1994; Belk et al., 2008). Reared fish populations also have less morphological variability than wild fish (Taylor, 1986), likely in response to the homogeneity of the farming environment (Taylor, 1986; Swain et al., 1991; Flemming et al., 1994; Hard et al., 2000; Belk et al., 2008). These differences between wild and reared fish often reflect the phenotypic plasticity of the fish, which adapt to the captive environment by developing morphological and behavioral traits that are advantageous in this environment rather than developing traits that would be advantageous in nature.

${ }^{1}$ Rua Chagas Sobrinho, no 116, Centro, 35540-000 Oliveira, MG, Brazil. sarahsaraiva@hotmail.com

${ }^{2}$ Setor de Ecologia, Departamento de Biologia, Universidade Federal de Lavras. P. O. Box 3037, $37200-000$ Lavras, MG, Brazil. pompeu@dbi.ufla.br. 
In an attempt to mitigate the effects of the hatchery environment on the phenotype of stocked fish and to increase the post-release survival rate, environmental enrichment of fish-farming tanks has been proposed by several researchers, however, fish behavior has been the main trait evaluated to assess the enrichment efficiency (Maynard et al., 1994; Berejikian et al., 2001; Brown \& Laland, 2001; Brown et al., 2003; Braithwaite \& Salvanes, 2005; Salvanes \& Braithwaite, 2006; Lee \& Berejikian, 2008; Roberts et al., 2011; Batzina \& Karakatsouli, 2012; Rand et al., 2012). The environmental enrichment can be defined as an improvement in the biological functioning of captive animals, resulting from modifications to their environment (Newberry, 1995). In the present study, we evaluated environmental enrichment as a tool for minimizing the effects of the captive environment on the morphology of reared fish. Belk et al. (2008) proposed the enrichment to obtain a suitable hatchery environment, which attempts to recreate the primary characteristics of natural environments. For neotropical migratory fish species, the addition of structural complexity may be particularly important, because these fish inhabit marginal lagoons in the early stages of development, which are environments rich in food and shelter provided by aquatic plants, wood debris, and other structures (Agostinho \& Júlio-Jr., 1999). In the present study, two species of migratory neotropical fish were cultivated in four types of tanks: one conventional and three enriched with submersed logs and artificial macrophytes. The two species chosen, Prochilodus lineatus and Brycon orbignyanus, are endangered by dams and have great importance for fishing, farming and cooking in Brazil. Our goal was to test the hypothesis that structural enrichment would induce morphological differentiation in the fishes and an increase in the morphological variability of reared populations, when compared to the control tank.

\section{Material and Methods}

\section{Studied species}

Prochilodus lineatus (Valenciennes, 1837) is a native migratory species of the Paraná River basin with detritivorous habits (Hahn et al., 2004) and is popularly known in Portuguese as 'curimba', 'curimbatá', 'curimatã', or 'papa-terra'. The adults of this species inhabit the primary channels of the rivers, and the juveniles develop in the marginal lagoons of floodplains, where they remain during the first two years of life (Agostinho \& Júlio-Jr., 1999). Due to its importance in fishing and cooking (Vaz et al., 2000), P. lineatus is one of the most used native migratory species in fish stocking and repopulation. It is even easy to handle in fish-farming, being commonly used as live food for other native species, especially piscivorous species, such as the Salminus brasiliensis, Zungaro jahu, and Brycon orbignyanus (Viveiros et al., 2009).

Brycon orbignyanus (Valenciennes, 1850), popularly known in Portuguese as 'piracanjuba', is also a migratory species of the Paraná River basin. It is threatened with extinction in the country (Agostinho et al., 2008), primarily due to dam construction, loss of riparian vegetation, pollution and fish introduction (Agostinho et al., 2008; Lopera-Barrero, 2009). Brycon orbignyanus is appreciated in commercial and sport fishing because of its active and aggressive behavior and the organoleptic properties of its meat (Vaz et al., 2000). In fish-farming it has good acceptance of artificial foods and agro-industrial by-products (Borba et al., 2006), but has high rates of cannibalism in the early stage of development, requiring feeding with post-larvae of other fish species (Reynalte-Tataje et al., 2002; Maciel et al., 2010).

\section{Reproduction}

To obtain fertilized eggs, we induced fish spawning at Volta Grande Hatchery Station, State of Minas Gerais, Brazil, at $20^{\circ} 01^{\prime} 33^{\prime \prime S} 48^{\circ} 13^{\prime} 10^{\prime \prime} \mathrm{W}$. Among the breeders of wild origin available in this station, three females and six males of $P$. lineatus were selected, as well as four females and eight males of $B$. orbignyanus, that were predisposed to reproduction. The breeders were kept in aquaria in trios of two males and one female. Spawning was induced by administering three doses of catfish crude pituitary extract, calculated according to the weight of each individual fish.

The newly fertilized eggs of the three $P$. lineatus trios were mixed together, as were the eggs from the four $B$. orbignyanus trios. They were then transferred to four incubators each, at a predetermined density.

The density control of post-larvae introduced per tank occurred during the egg stage, from the calculation of the fertilization rate (hatched eggs per milliliter), which determined how many viable eggs we had per milliliter and what volume of eggs was required to generate the post-larval density set for each tank. Each tank was approximately $8 \mathrm{~m}^{2}$, and the density set for $P$. lineatus was 300 post-larvae per $\mathrm{m}^{2}(2400$ post-larvae per tank), while the density for $B$. orbignyanus was 200 post-larvae per $\mathrm{m}^{2}$ (1600 post-larvae per tank). These densities were previously defined to obtain a minimum sample of 50 fish after two months of the experiment, considering the likely mortality rates (according to the database of the Fishfarming Station of Volta Grande). The density of the $B$. orbignyanus tanks was set lower to minimize the cannibalism that is commonly observed in this species. Three days after hatching, the post-larvae from each incubator and from each species were transferred to the tanks.

\section{Treatments}

The post-larvae of both species were grown in eight identical tanks (four for each species) made of concrete, with a soil bottom $\left(8.49 \mathrm{~m}^{2}\right.$ and $0.75 \mathrm{~m}$ deep $)$ and constantly renewed and filtered water, covered with shading screen to avoid predation by birds and to reduce the incidence of solar radiation. The enrichment was performed before the introduction of post-larvae, with tree logs and artificial aquatic plants. Each tank comprised a treatment, four for each species as described in the Fig. 1.

The eucalyptus logs used in the treatment L were kept submersed in water for one month prior to the assembly of the experiment, to eliminate possible resins or other chemicals 
Control (C)

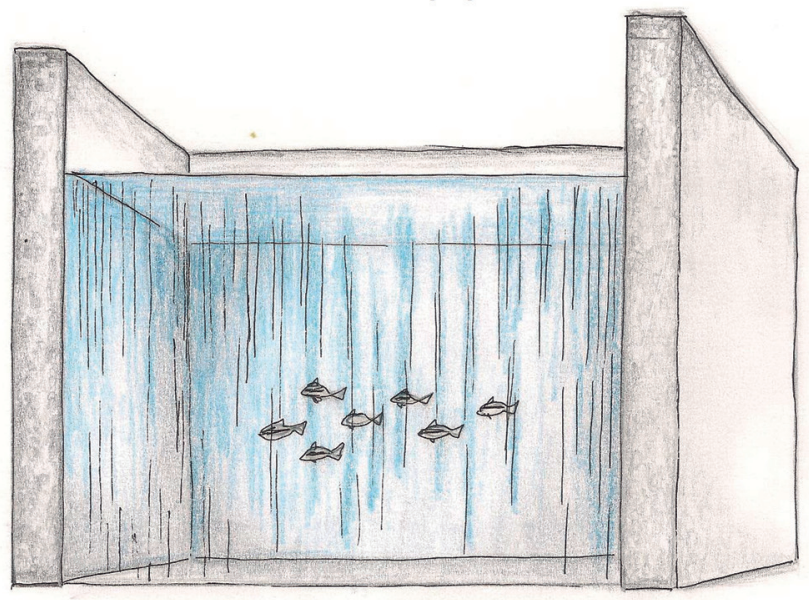

Artificial macrophytes (M)

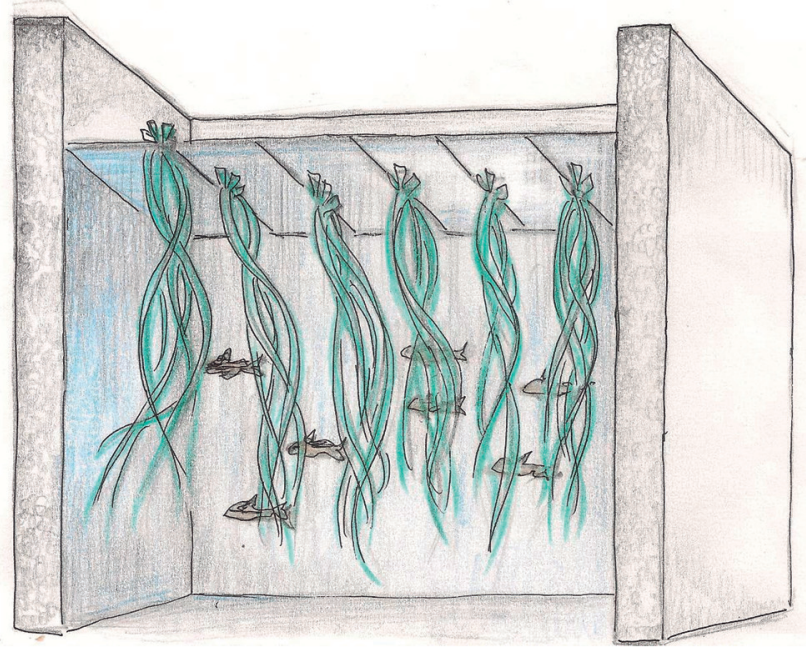

Logs (L)

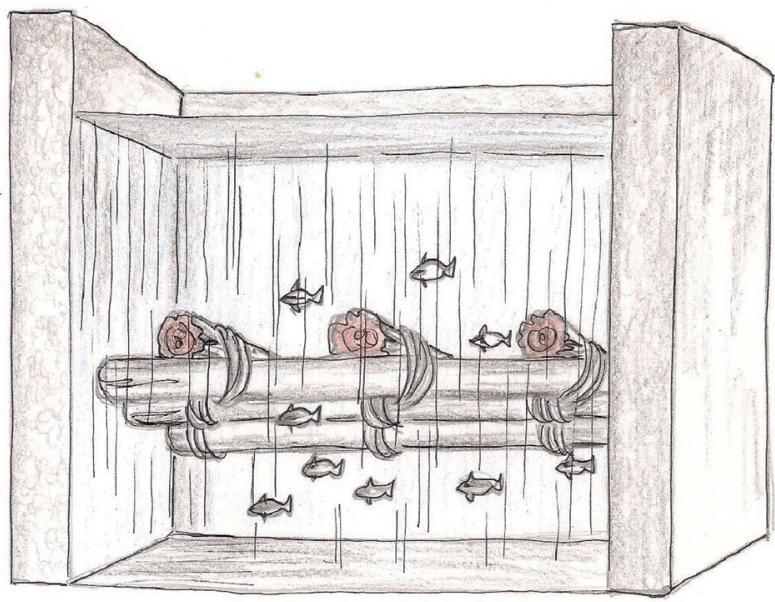

Logs and artificial macrophytes (B)

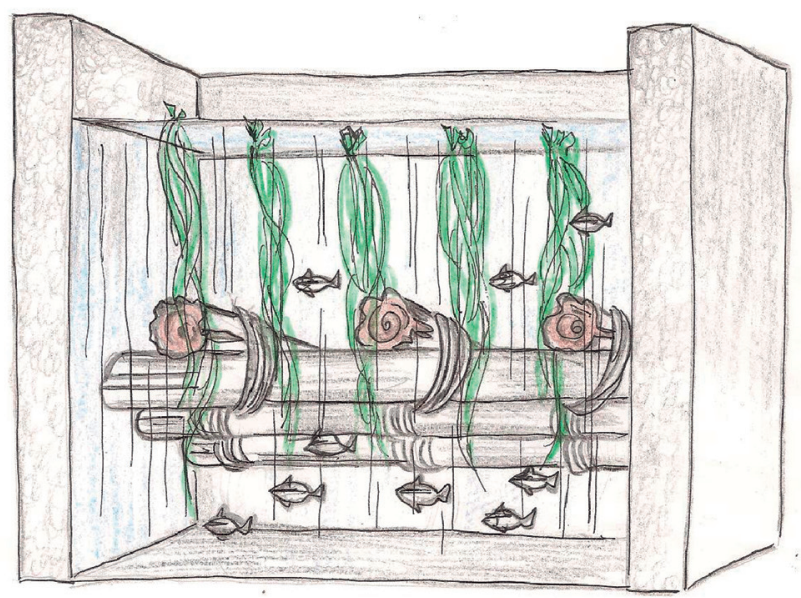

Fig. 1. Schematic drawing of the four types of structuring applied in the tanks: Control: the tank did not receive any type of structuring; Logs: the tank was structured with six eucalyptus tree logs, set in the middle of the tank so that they were submersed after the tank was filled. Three of the logs were arranged along the tank and the other three were arranged perpendicular; Artificial macrophytes: the tank received plastic macrophytes hung on a kind of clothesline placed above the tank, so that the plastic filaments came in contact with the water. Each tank received twenty five plastic macrophytes, arranged in five parallel rows of five plants each; Logs and artificial macrophytes: the tank received both types of structures, submersed logs and artificial macrophytes.

in advance. The artificial macrophytes used in the treatment M were made from plastic bags with cutouts in strips, forming a folded structure that mimicked the tangle of roots and leaves of a floating aquatic plant. In the treatment $\mathrm{B}$, the tank received both types of structures, in the same amounts and arrangements as described for prior treatments.

All the post-larvae were introduced into the tanks in the same day and stayed under the treatment conditions for two months. During this time, fish were fed once a day with commercial pellets for tropical fish (52\% crude protein) and all tanks received the same amount.

\section{Collections}

The experiments lasted for two months (from January to March 2012). To collect the fish, the water level was reduced and 50 fish in each tank were captured with dip nets. After collection these fish were anesthetized with clove oil, fixed in $10 \%$ formalin, and preserved in $70 \%$ alcohol. The voucher specimens were deposited in the Ichthyological Collection of Universidade Federal de Lavras (CI-UFLA 786 -787).

\section{Morphometry}

From each collected individual, 27 morphometric measures 
were taken (Table 1). The linear measurements were obtained directly from the fish body with a digital caliper $(0.01 \mathrm{~mm}$ precision), and drawings of the outline of the body and fins of each fish were made on paper to obtain the body and fin areas. The drawings were then scanned and the areas were calculated using the Image J software.

From the morphometric measurements, 21 ecomorphological attributes were calculated (Table 2), which were chosen according to their ecological meanings, as defined in the literature.

\section{Statistical Analyses}

To evaluate whether the structuring of the tanks affects growth and nutritional status of fish, the standard lengths of the individuals from different treatments were compared using histograms and its condition factors (CFs) were calculated using the formula:

$$
C F=\frac{W}{(S L)^{b}},
$$

where $\mathrm{W}$ is the weight, SL is the standard length, and $b$ is the slope of the regression line between the weight and the length. Having established the normality of the data, the condition factors were compared between treatments by analyses of variance (ANOVA).

Principal Component Analysis (PCA) was used to evaluate the distribution of individuals from each treatment in the morphological space for each species. Then, to determine differences between treatments in the first two PCA axes, first an ANOVA was performed, followed by a Tukey's test. A Discriminant Analysis (DCA) was also applied as an alternative analysis to ANOVA.

To verify the morphological variability of samples for each treatment, a matrix of normalized Euclidean distances between pairs of individuals from the ecomorphological attributes was constructed. From each distance matrix, the distance of each individual to the centroid of its population (DC) was identified. The average DC is an estimate of the relative size of the morphological hypervolume occupied by the population (Winemiller, 1991), which corresponds to the morphological variability. To evaluate possible differences between the morphological variability of the populations of each treatment, we conducted an ANOVA with a subsequent Tukey's test for each species. The DC data were normalized through log transformations, prior to proceeding with the ANOVA.

\section{Results}

The standard lengths of individuals were influenced by the treatments (Fig. 2). Brycon orbignyanus was longer in the treatments L and M, when compared with the control. Prochilodus lineatus experienced an observable influence only in the $M$ treatment, where most of the fish were concentrated in a single range of length (30 to $40 \mathrm{~mm}$ ). It was also noticeable that $B$. orbignyanus had a much higher average length than $P$. lineatus, though individuals from both species were the same age and were grown under the same conditions.

The condition factors were different among the treatments (Fig. 3). For P. lineatus, the lowest condition factor was found in treatment $\mathrm{M}$, which was statistically similar to treatment $\mathrm{B}$, while treatments $\mathrm{C}$ and $\mathrm{L}$ had higher values. Comparing the graphs of the condition factors and standard lengths, it is

Table 1. Morphometric measurements taken from examined individuals and their descriptions.

\begin{tabular}{|c|c|c|c|}
\hline & Measurement & Acronym & Description \\
\hline 1. & Standard length & SL & Distance from the tip of the snout to the end of the caudal peduncle \\
\hline 2. & Body height & $\mathrm{BH}$ & Greatest dorsoventral distance perpendicular to the major body axis \\
\hline 3. & Body width & BW & Greatest side-to-side width of the body \\
\hline 4. & Mean body height & MH & Distance from the belly to the line that transects the body from the mouth to the caudal fin \\
\hline 5. & Body area & BA & Area of the body plus the area of the caudal fin \\
\hline 6. & Head length & $\mathrm{HeL}$ & Distance from the tip of the snout to the end of the operculum \\
\hline 7. & Head height & $\mathrm{HeH}$ & Distance between the ventral and dorsal part of the head at the level of the eyes \\
\hline 8. & Eye height & EH & Distance from the center of the eye to the lower maxilla \\
\hline 9. & Eye area & EA & Eye diameter times pi $(\pi)$ \\
\hline 10. & Length of the caudal peduncle & LCdP & Distance from the end of the anal fin to the start of the caudal fin \\
\hline 11. & Height of the caudal peduncle & $\mathrm{HCdP}$ & Height of the peduncle measured at the same point as width \\
\hline 12. & Width of the caudal peduncle & WCdP & Width of the peduncle measured at its midpoint \\
\hline 13. & Length of the dorsal fin & LDsF & Insertion line of the fin base parallel to the body \\
\hline 14. & Height of the dorsal fin & HDsF & Distance between the base and top of the fin \\
\hline 15. & Area of the dorsal fin & $\mathrm{ADsF}$ & Area of the fully extended dorsal fin \\
\hline 16. & Length of the caudal fin & $\mathrm{LCdF}$ & Distance between the end of the caudal peduncle and the tip of the fin \\
\hline 17. & Height of the caudal fin & $\mathrm{HCdF}$ & Maximum distance between the two ends of the fully extended fin \\
\hline 18. & Area of the caudal fin & $\mathrm{ACdF}$ & Area of the fully extended caudal fin \\
\hline 19. & Length of the anal fin & LAnF & Distance between the base of the fin and its tip \\
\hline 20. & Width of the anal fin & WAnF & Maximum distance between the two ends of the fully extended fin \\
\hline 21. & Area of the anal fin & AAnF & Area of the fully extended anal fin \\
\hline 22. & Length of the pelvic fin & LPIF & Distance between the base of the fin and its tip \\
\hline 23. & Width of the pelvic fin & WPIF & Maximum distance between the two ends of the fully extended fin \\
\hline 24. & Area of the pelvic fin & APIF & Area of the fully extended pelvic fin \\
\hline 25. & Length of the pectoral fin & LPtF & Distance between the base of the fin and its tip \\
\hline 26. & Width of the pectoral fin & WPtF & Greatest width of the fin along an axis perpendicular to the long axis of the fully extended fin \\
\hline 27. & Area of the pectoral fin & APtF & Area of the fully extended pectoral fin \\
\hline
\end{tabular}


clear that the $P$. lineatus in tanks containing macrophytes were less developed, being thinner and smaller than the other fish. Although there was no significant difference observed between treatments $\mathrm{C}$ and $\mathrm{L}$, P. lineatus in treatment $\mathrm{L}$ had higher average condition factor values and a larger number of individuals in higher length classes. For B. orbignyanus, the highest condition factor occurred for the fishes in tank $C$, but these did not differ significantly from the fishes in tank B. Fishes in tank $\mathrm{L}$ had the lowest condition factor, followed by the fishes in tank M.

The PCA indicated that the populations corresponding to each of the treatments occupied distinct morphological spaces. For P. lineatus (Fig. 4a), it was possible to observe that each treatment tended to occupy a specific region of the morphological space, although there was some overlap among them. For B. orbignyanus (Fig. 4b), we observed that the C and $\mathrm{B}$ treatments were completely different from the $\mathrm{L}$ and $\mathrm{M}$ treatments, although there was no differentiation between the latter two treatments.

The first two PCA axes were important for explaining the variance among treatments for $P$. lineatus and $B$. orbignyanus. The first axis accounted for $18.20 \%$ of the total variation for $P$. lineatus and the second axis for $11.93 \%$; that is, considering these PCA axes, the analyzed ecomorphological attributes explained $30 \%$ of the total variance between the treatments of $P$. lineatus. Among the analyzed attributes, those that most contributed to the differentiation between treatments in Axis 1 (considering contributions higher than 0.7 ) were compression index of the caudal peduncle, relative eye area, relative head length and relative area of the anal fin. In axis two, these were relative area of the pelvic fin and relative area of the pectoral fin. For B. orbignyanus, the first axis explained

Table 2. Description of ecomorphological traits and their ecological significance.

\begin{tabular}{|c|c|c|c|}
\hline & Trait & Formula & Interpretation \\
\hline 1. & Compression index & $\mathrm{CI}=\mathrm{BH} / \mathrm{BW}$ & $\begin{array}{l}\text { High values indicate laterally compressed fish, which inhabit sites with low water } \\
\text { velocity (Watson \& Balon, 1984). }\end{array}$ \\
\hline 2. & Index of ventral flattening & $\mathrm{IVF}=\mathrm{MH} / \mathrm{BH}$ & $\begin{array}{l}\text { Low values are typical of fish living in water with high velocity, allowing them to } \\
\text { maintain position without swimming (Hora, 1930). }\end{array}$ \\
\hline 3. & Relative body height & $\mathrm{RBH}=\mathrm{BH} / \mathrm{SL}$ & $\begin{array}{l}\text { This index is inversely related to water velocity and directly related to the ability } \\
\text { to perform vertical displacements }(\mathrm{Gatz}, 1979) \text {. }\end{array}$ \\
\hline 4. & Relative eye position & $\mathrm{REP}=\mathrm{EH} / \mathrm{HeH}$ & $\begin{array}{l}\text { This index is related to the detection of food, provides information on the use of } \\
\text { vision during predatory activities (Pouilly et al., 2003) and indicates the preferred } \\
\text { position in the water column (Gatz, 1979). }\end{array}$ \\
\hline 5. & Relative eye area & $\mathrm{REA}=\mathrm{EA} /(\mathrm{SL})^{2}$ & $\begin{array}{l}\text { This index is related to the detection of food and provides information on the use } \\
\text { of vision during predatory activities (Pouilly et al., 2003). }\end{array}$ \\
\hline 6. & Relative head length & $\mathrm{RHeL}=\mathrm{HeL} / \mathrm{SL}$ & $\begin{array}{l}\text { Directly related to prey size, and high values suggest predatory species with } \\
\text { relatively large prey (Gatz, 1979). }\end{array}$ \\
\hline 7. & $\begin{array}{l}\text { Relative length of the caudal } \\
\text { peduncle }\end{array}$ & $\mathrm{RLCdP}=\mathrm{LCdP} / \mathrm{SL}$ & $\begin{array}{l}\text { Relatively long peduncles indicate fish that inhabit turbulent waters and have a } \\
\text { good swimming ability (Gatz, 1979; Watson \& Balon, 1984). }\end{array}$ \\
\hline 8. & $\begin{array}{l}\text { Relative height of the caudal } \\
\text { peduncle }\end{array}$ & $\mathrm{RHCdP}=\mathrm{HCdP} / \mathrm{BH}$ & Low values indicate greater maneuverability (Winemiller, 1991). \\
\hline 9. & $\begin{array}{l}\text { Relative width of the caudal } \\
\text { peduncle }\end{array}$ & $\mathrm{RWCdP}=\mathrm{WCdP} / \mathrm{BW}$ & High values indicate better long-distance swimmers (Winemiller, 1991). \\
\hline 10. & $\begin{array}{l}\text { Compression index of the } \\
\text { caudal peduncle }\end{array}$ & $\mathrm{CICdP}=\mathrm{HCdP} / \mathrm{WCdP}$ & $\begin{array}{l}\text { This index is inversely related to the amplitude of swimming motions, with high } \\
\text { values indicating compressed peduncles typical of less active swimmers (Gatz, } \\
\text { 1979). }\end{array}$ \\
\hline 11. & $\begin{array}{l}\text { Relative area of the dorsal } \\
\text { fin }\end{array}$ & $\mathrm{RADsF}=\mathrm{ADsF} / \mathrm{BA}$ & $\begin{array}{l}\text { Dorsal fins with a large area are better able to stabilize during deviations } \\
\text { (Gosline, 1971). }\end{array}$ \\
\hline 12. & $\begin{array}{l}\text { Relative area of the caudal } \\
\text { fin }\end{array}$ & $\mathrm{RACdF}=\mathrm{ACdF} / \mathrm{BA}$ & $\begin{array}{l}\text { High values indicate fins able to produce rapid impulses, which are typical of the } \\
\text { swimming of many benthonic fishes (Watson \& } \\
\text { Balon, 1984). }\end{array}$ \\
\hline 13. & Aspect ratio of the caudal fin & $\mathrm{ARCdF}=(\mathrm{HCdF})^{2} / \mathrm{ACdF}$ & $\begin{array}{l}\text { This index is directly proportional to the amount of swimming performed by the } \\
\text { fish (Gatz, 1979). }\end{array}$ \\
\hline 14. & Relative area of the anal fin & $\mathrm{RAAnF}=\mathrm{AAnF} /(\mathrm{SL})^{2}$ & $\begin{array}{l}\text { Large relative areas indicate high maneuverability and ability for stabilizing } \\
\text { motions (Breda et al., 2005). }\end{array}$ \\
\hline 15. & Aspect ratio of the anal fin & $\mathrm{ARAnF}=(\mathrm{LAnF})^{2} / \mathrm{AAnF}$ & $\begin{array}{l}\text { Anal fins with a high aspect ratio indicate good ability for rapid movements of } \\
\text { progression and regression (Breda et al., 2005) }\end{array}$ \\
\hline 16. & $\begin{array}{l}\text { Relative length of the pelvic } \\
\text { fin }\end{array}$ & $\mathrm{RLPIF}=\mathrm{LPIF} / \mathrm{SL}$ & $\begin{array}{l}\text { Related to habitat preference, with a longer index in rocky habitats and a shorter } \\
\text { one in nektonic species (Gatz, 1979). }\end{array}$ \\
\hline 17. & $\begin{array}{l}\text { Relative area of the pelvic } \\
\text { fin }\end{array}$ & $\mathrm{RAPlF}=\mathrm{APIF} / \mathrm{BA}$ & Benthonic fishes have relatively large areas (Gatz, 1979). \\
\hline 18. & Aspect ratio of the pelvic fin & $\mathrm{ARPIF}=\mathrm{LPIF} / \mathrm{WPIF}$ & $\begin{array}{l}\text { Low values are found in fish that use the pelvic fins for braking and swimming } \\
\text { forward, and greater values are found in fish that use these fins to retreat and } \\
\text { maintain their position in the water column (Gatz, 1979). }\end{array}$ \\
\hline 19. & $\begin{array}{l}\text { Relative length of the } \\
\text { pectoral fin }\end{array}$ & $\mathrm{RLPtF}=\mathrm{LPtF} / \mathrm{SL}$ & $\begin{array}{l}\text { High values indicate fish that inhabit slow waters and perform many maneuvers } \\
(\text { Gatz, 1979). }\end{array}$ \\
\hline 20. & $\begin{array}{l}\text { Relative area of the pectoral } \\
\text { fin }\end{array}$ & $\mathrm{RAPtF}=\mathrm{APtF} / \mathrm{BA}$ & $\begin{array}{l}\text { High values indicate slow swimmers, which use these fins to maneuver, and fish } \\
\text { inhabiting rapid waters, which use them as water deflection surfaces to keep their } \\
\text { body close to the substrate (Watson \& Balon, 1984). }\end{array}$ \\
\hline 21. & $\begin{array}{l}\text { Aspect ratio of the pectoral } \\
\text { fin }\end{array}$ & $\mathrm{ARPtF}=\mathrm{LPtF} / \mathrm{WPtF}$ & $\begin{array}{l}\text { High values indicate long fins and suggest fish with good swimming ability } \\
\text { (Watson \& Balon, 1984). }\end{array}$ \\
\hline
\end{tabular}



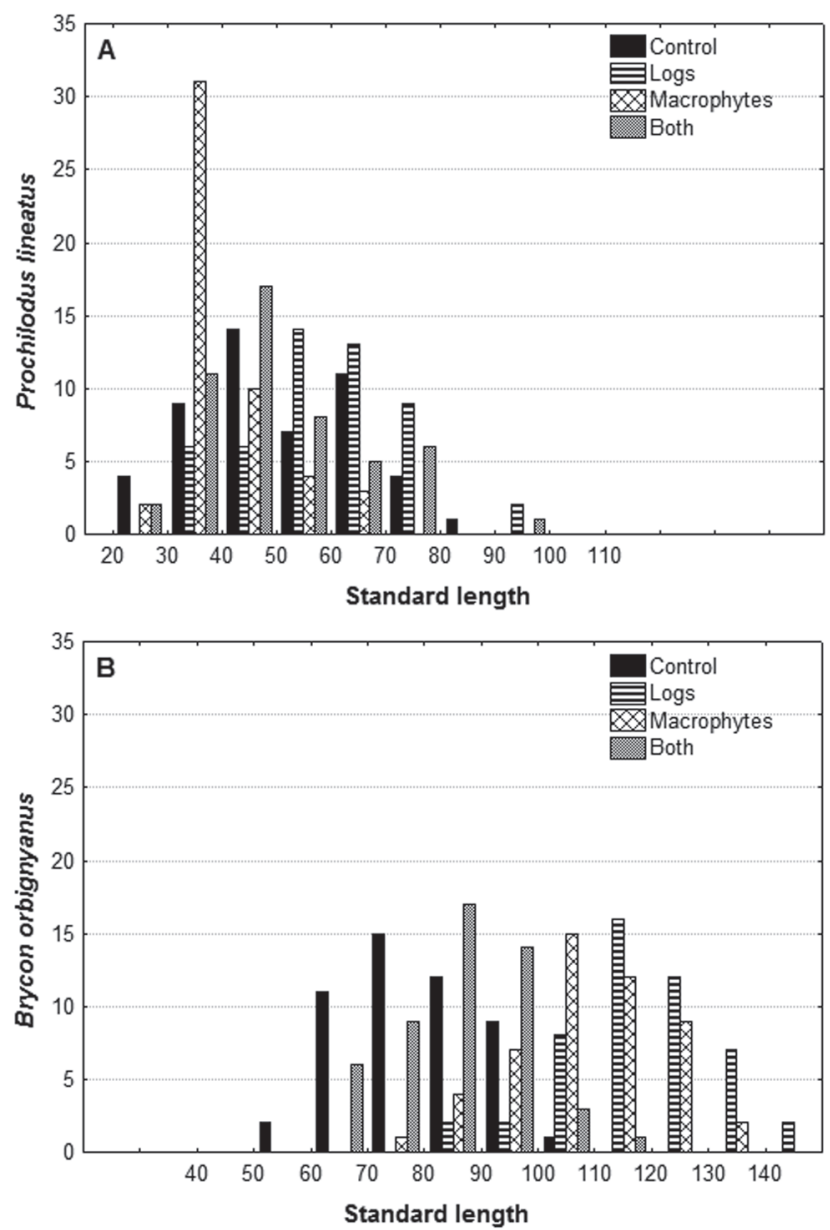

Fig. 2. The number of individuals for each species per class of standard length for each treatment.

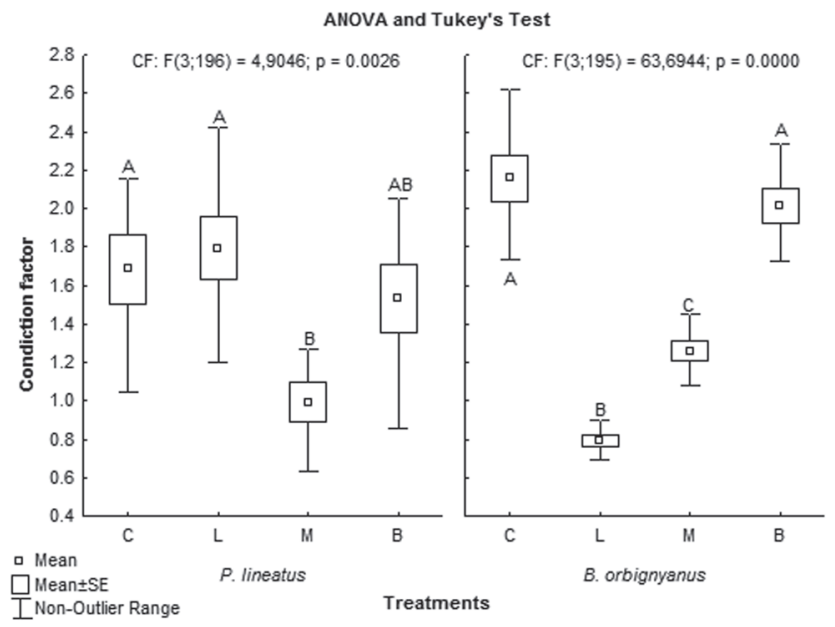

Fig. 3. Condition factors (CFs) for Prochilodus lineatus and Brycon orbignyanus. The ANOVA was significant for both species $(\mathrm{p}<0.0001)$, demonstrating significant differences among the treatments. The results of the Tukey tests specifying which CFs were different from each other is demonstrated by the letters A, B, and C. Different letters indicate significant differences among the treatments.
$28.91 \%$ of the variation and the second axis $10.21 \%$, together explaining $39 \%$ of the total variance. The attributes that most contributed to this were relative head length, relative eye area, relative area of the dorsal fin, relative area of the pelvic fin, relative area of the caudal fin, and relative area of the pectoral fin, in the first axis, and relative body height and relative height of the caudal peduncle, in the second axis.

The ANOVA performed between the scores of the first two axes of the PCA showed significant differences among the treatments in both axes, both for P. lineatus (PCA 1: $\mathrm{p}<$ $0.001 ; \mathrm{MS}=55.7795 ; \mathrm{F}=18.5625 ; \mathrm{PCA} 2: \mathrm{p}<0.001 ; \mathrm{MS}=$ $86.3683 ; \mathrm{F}=70.6724$ ) and for B. orbignyanus (PCA $1: \mathrm{p}<$ $0.001 ; \mathrm{MS}=321.8348 ; \mathrm{F}=265.1557 ; \mathrm{PCA} 2: \mathrm{p}<0.001 ; \mathrm{MS}=$ $14.0155 ; \mathrm{F}=7.1489)$. This analysis shows that the ecomorphological attributes that were more important in these axes comprise the primary sources of morphological differentiation among the treatments.

The Tukey's test showed that, for P. lineatus, the only treatments that did not differ from the first axis of the PCA
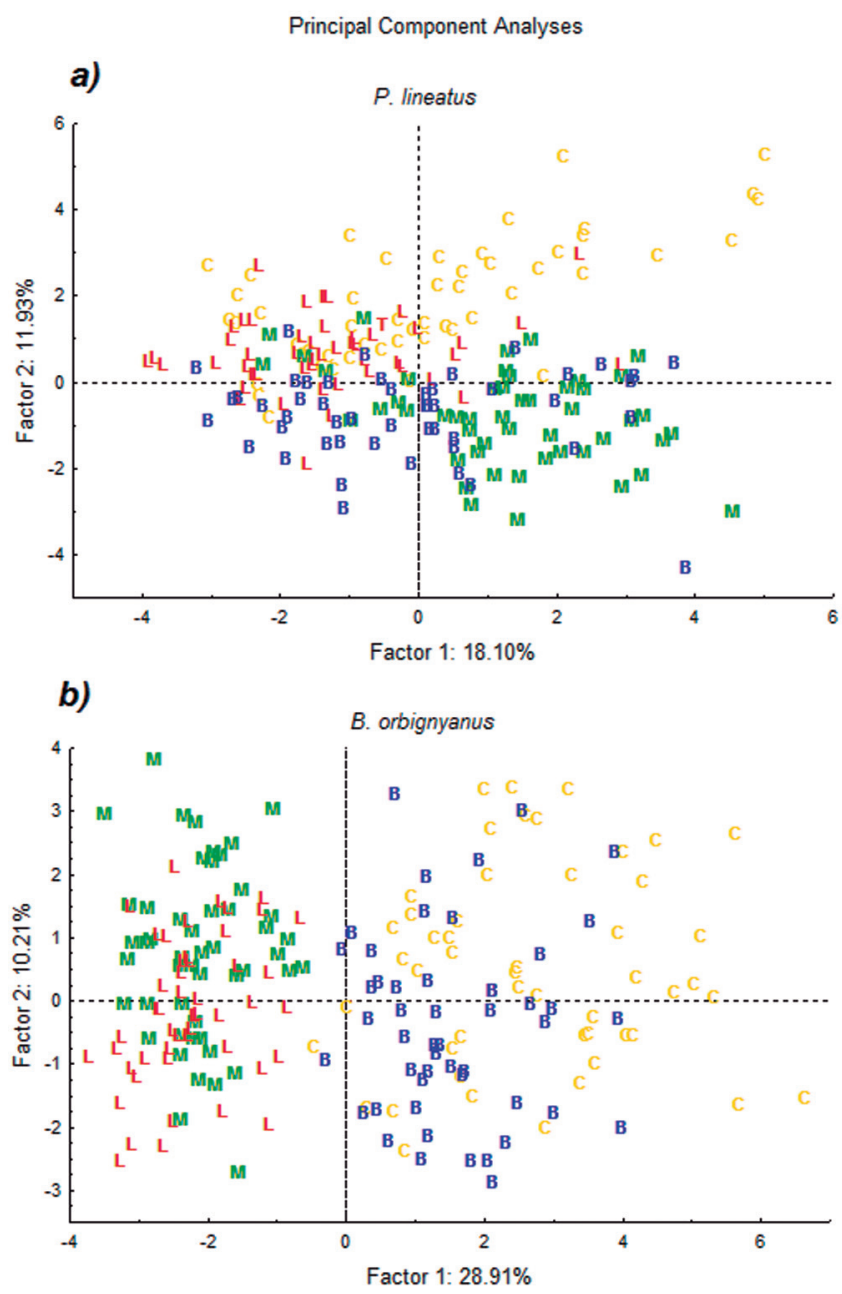

Fig. 4. Projection of the four treatments $[\mathrm{C}=$ control; $\mathrm{L}=\operatorname{logs}$; $\mathrm{M}=$ macrophytes; and $\mathrm{B}=$ both (logs + macrophytes $)]$ in the first two axes of the Principal Component Analysis for Prochilodus lineatus and for Brycon orbignyanus. 
were $\mathrm{C}$ and $\mathrm{B}$ and, in the second axis, $\mathrm{M}$ and $\mathrm{B}$ (Table 3). For B. orbignyanus, in the first axis, $\mathrm{L}$ did not differ from $\mathrm{M}$, and in the second axis, $\mathrm{C}$ was not different from $\mathrm{L}$ or $\mathrm{M}$, and $\mathrm{L}$ did not differ from $\mathrm{B}$ (Table 3 ).

The DCA performed was also significant for $P$. lineatus (Wilks Lambda: 0.14596; F $(63,526)=7.5625 ; \mathrm{p}<0.0001)$ and for B. orbignyanus (Wilks Lambda: $0.04004 ; \mathrm{F}(63.523)=16.102$; $\mathrm{p}<0.0001$ ), except that all four treatments were different (Table 4). The ecomorphological attributes that contributed significantly to the differentiation among treatments of $P$. lineatus were: relative head length (RHeL: $\mathrm{F}(3.176)=3.9964$; $\mathrm{p}=0.0087)$, compression index of the caudal peduncle (CICdP: $F(3.176)=5.0068 ; p=0.0023)$, relative area of the dorsal fin $($ RADsF: $F(3.176)=17.6683 ; p<0.0001)$, relative area of the caudal fin (RACdF: $\mathrm{F}(3.176)=3.5822 ; \mathrm{p}=0.0150)$, aspect ratio of the anal fin (ARAnF: $F(3.176)=3.5513 ; \mathrm{p}=0.0156)$, relative length of the pelvic fin (RLPIF: $F(3.176)=2.8963 ; p=0.0366$ ) and relative area of the pectoral fin (RAPtF: $\mathrm{F}(3.176)=21.55333$; $\mathrm{p}<0.0001)$. For $B$. orbignyanus they were: relative body height (RBH: $F(3.175)=6.1720 ; p=0.0005)$, relative eye position (REP: $F(3.175)=2.8230 ; p=0.0403$ ), relative eye area (REA: $F$

Table 3. Results of the Tukey's test for the treatments [C = control; $\mathrm{L}=\operatorname{logs} ; \mathrm{M}=$ macrophytes; and $\mathrm{B}=$ both (logs+macrophytes)] of Prochilodus lineatus and Brycon orbignyanus from the first two axes of the Principal Component Analysis.

\begin{tabular}{|c|c|c|c|c|c|c|c|c|c|}
\hline & \multicolumn{4}{|c|}{ PCA 1} & \multicolumn{5}{|c|}{ PCA 2} \\
\hline & & $\mathrm{C}$ & $\mathrm{L}$ & $M$ & B & $\mathrm{C}$ & $\mathrm{L}$ & $\mathrm{M}$ & B \\
\hline \multirow{4}{*}{ 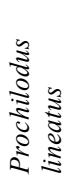 } & $\mathrm{C}$ & & & & & & & & \\
\hline & $\mathrm{L}$ & $<0.01$ & & & & $<0.01$ & & & \\
\hline & M & 0.01 & $<0.01$ & & & $<0.01$ & $<0.01$ & & \\
\hline & B & 0.69 & $<0.01$ & $<0.01$ & & $<0.01$ & $<0.01$ & 0.99 & \\
\hline \multirow{4}{*}{ 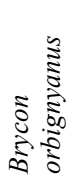 } & $\mathrm{C}$ & & & & & & & & \\
\hline & $\mathrm{L}$ & $<0.01$ & & & & 0.09 & & & \\
\hline & M & $<0.01$ & 0.91 & & & 0.79 & $<0.01$ & & \\
\hline & B & $<0.01$ & $<0.01$ & $<0.01$ & & 0.01 & 0.88 & $<0.01$ & \\
\hline
\end{tabular}

Table 4. P-values of the Discriminant Analysis among the treatments $[\mathrm{C}=$ control; $\mathrm{L}=\operatorname{logs} ; \mathrm{M}=$ macrophytes; and $\mathrm{B}=$ both (logs+macrophytes)] for Prochilodus lineatus and Brycon orbignyanus.

\begin{tabular}{|c|c|c|c|c|c|}
\hline & $\begin{array}{l}\text { Treatme } \\
\text { nts }\end{array}$ & $\mathrm{C}$ & $\mathrm{L}$ & $\mathrm{M}$ & B \\
\hline \multirow{4}{*}{ 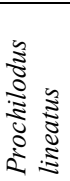 } & $\mathrm{C}$ & & & & \\
\hline & $\mathrm{L}$ & $<0.0001$ & & & \\
\hline & M & $<0.0001$ & $<0.0001$ & & \\
\hline & B & $<0.0001$ & $<0.0001$ & $<0.0001$ & \\
\hline \multirow{4}{*}{ 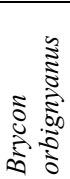 } & $\mathrm{C}$ & & & & \\
\hline & $\mathrm{L}$ & $<0.0001$ & & & \\
\hline & M & $<0.0001$ & $<0.0001$ & & \\
\hline & B & $<0.0001$ & $<0.0001$ & $<0.0001$ & \\
\hline
\end{tabular}

$(3.175)=9.38258 ; \mathrm{p}<0.0001)$, relative head length $($ RHeL: $\mathrm{F}$ $(3.175)=3.2163 ; \mathrm{p}=0.0242)$, relative length of the caudal peduncle (RLCdP: $F(3.175)=5.5311 ; \mathrm{p}=0.0012)$, relative area of the dorsal fin (RADsF: F $(3.175)=13.9796 ; \mathrm{p}<0.0001)$, relative area of the anal fin (RAAnF: $F(3.175)=5.73337$; $\mathrm{p}=$ $0.0009)$, aspect ratio of the anal fin (ARAnF: $F(3.175)=2.8688$; $\mathrm{p}=0.0379)$, relative length of the pelvic fin (RLPIF: $F(3.175)=$ $6.8815 ; \mathrm{p}=0.0002$ ), relative area of the pelvic fin (RAPIF: $F$ $(3.175)=6.4926 ; p=0.0003)$, relative area of the pectoral fin (RAPtF: $F(3.175)=4.2149 ; p=0.0066)$ and aspect ratio of the pectoral fin (ARPtF: $\mathrm{F}(3.175)=9.64333 ; \mathrm{p}<0.0001)$.

Comparing the attributes that most contributed to the differentiation between the treatments through the first two PCA axes and through DCA, both analyses showed relative head length, compression index of the caudal peduncle and relative area of the pectoral fin as the most important ecomorphological attributes for $P$. lineatus and relative body height, relative eye area, relative head length, relative area of the dorsal fin, relative area of the pelvic fin and relative area of the pectoral fin as the most important attributes for $B$. orbignyanus. All of these attributes underwent significant changes when compared with the control (Figs. 5, 6). The enrichment most strongly altered morphological traits related to the head, caudal peduncle, and pectoral fin of $P$. lineatus and traits related to the body, eye, head, and dorsal, pelvic, and pectoral fins of $B$. orbignyanus. Therefore, $B$. orbignyanus underwent more changes than $P$. lineatus.

The effect of the treatments on the morphological variability of the fish was analyzed by the centroid distance graph (Fig. 7). For P. lineatus, there was a significant increase in the morphological variability with the addition of physical structuring. It was observed that the effect of the artificial macrophytes on the reared population was higher than the effect of the logs, and the simultaneous effect of the logs and the macrophytes was higher than macrophytes alone. As for B. orbignyanus, the treatments worked differently. There was no tendency towards an increase in variability with the environmental enrichment; on the contrary, the highest morphological variability was found for the control treatment.

\section{Discussion}

In the present study, fish reared in enriched tanks became morphologically distinct from those raised in conventional tanks. Previous studies have evaluated the effect of enrichment on reared fish. Specifically in relation to the morphology, Garduño-Paz et al. (2010) compared fish in two types of environments: a simple environment (with gravel at the bottom) and a complex one (with gravel, large stones with interstitial spaces, and artificial macrophytes). They found significant differences in the shape of the body and the head of the fish between these two environments, likely increasing the ability to swim among stones and plants and to forage in interstitial spaces in the complex environment. From these results Garduño-Paz et al. (2010) showed that the structural complexity of the environment was capable of inducing the 

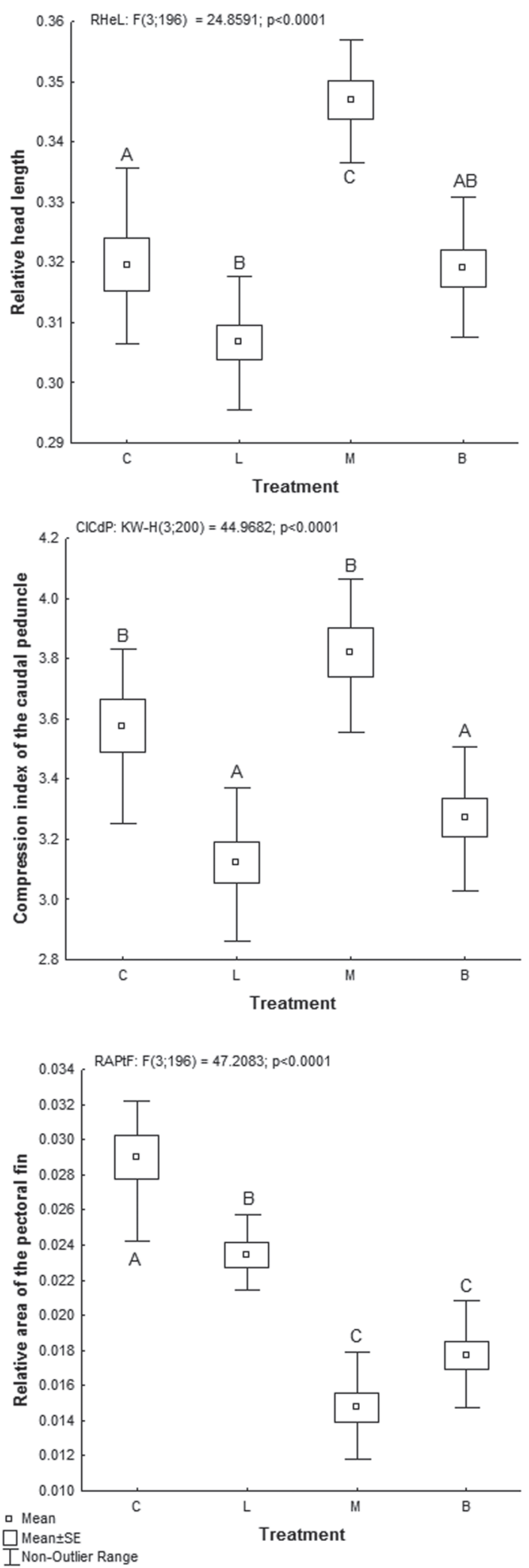

Fig. 5. Most important ecomorphological attributes for Prochilodus lineatus in the morphological differentiation among treatments, according to the ANOVA and the DCA, concomitantly. Treatments with a different letter above their ranges differed significantly. expression of morphological traits through phenotypic plasticity during the fish development.

In the present study, in addition to detecting that the structural enrichment induced morphological differences in the fishes via phenotypic plasticity, we also noted that each species responded in a different manner to the treatments. Brycon orbignyanus had a smaller head and larger areas of the dorsal, pelvic, and pectoral fins when reared in structured tanks. Such characteristics may be better suited to swimming and foraging between logs and macrophytes, as smaller heads facilitate the exploring of interstitial spaces, and larger fin areas have been directly related to the ability to perform maneuvers and turns (Gosline, 1971; Watson \& Balon, 1984). Individuals of $P$. lineatus reared in structured tanks had smaller pectoral fins, which contradicts the expected, since bigger fins would facilitate the ability to maneuver between structures (Gatz, 1979).

In addition to the treatments having changed the ecomorphological attributes, generating morphologically distinct fish, they also affected the morphological variability of the fish. In this study, the environmental enrichment aimed to make hatchery conditions closer to the natural, generating fish that are more similar to wild fish, which have high morphological variability. The enrichment acted as an inducer of variability for $P$. lineatus, since the higher the tank structuring, the higher the heterogeneity and environmental complexity provided, and the higher the morphological variability. Juveniles of neotropical migratory fish inhabit heterogeneous environments, the marginal lagoons, which are rich in aquatic plants, dry sticks, and other types of structures (Agostinho \& Júlio-Jr., 1999). The structural complexity of these lagoons largely explains the morphological variability of wild fish. However, reared fish have less morphological variation than wild fish of the same species (Taylor, 1986), likely in response to the homogeneity of the hatchery environment (Taylor, 1986; Swain et al., 1991; Flemming et al., 1994; Hard et al., 2000; Belk et al., 2008).

In turn, the population of $B$. orbignyanus did not respond as initially expected. The greatest morphological variability was found in the control tank. One possible explanation could be the suggestion that the hatchery environment represents a mild environment that does not induce any morphological variations (Belk et al., 2008). When the environment provides plenty of food, a lack of predators, and an absence of sharp environmental variation, selective pressures are weaker, allowing fish to have some flexibility during development, resulting in high morphological variety, as what happened with $B$. orbignyanus. In treatments $\mathrm{L}$ and $\mathrm{M}$, the morphological variability was strongly reduced, suggesting that, in the case of the addition of a single type of structure (logs or artificial macrophytes), the selective pressure of the tank increases, promoting morphological patterns specifically adapted to that structure and reducing the morphological variability. In treatment $\mathrm{B}$, in which two types of structures were present, the morphological variability rose again, indicating that, in this case, the environment became increasingly 

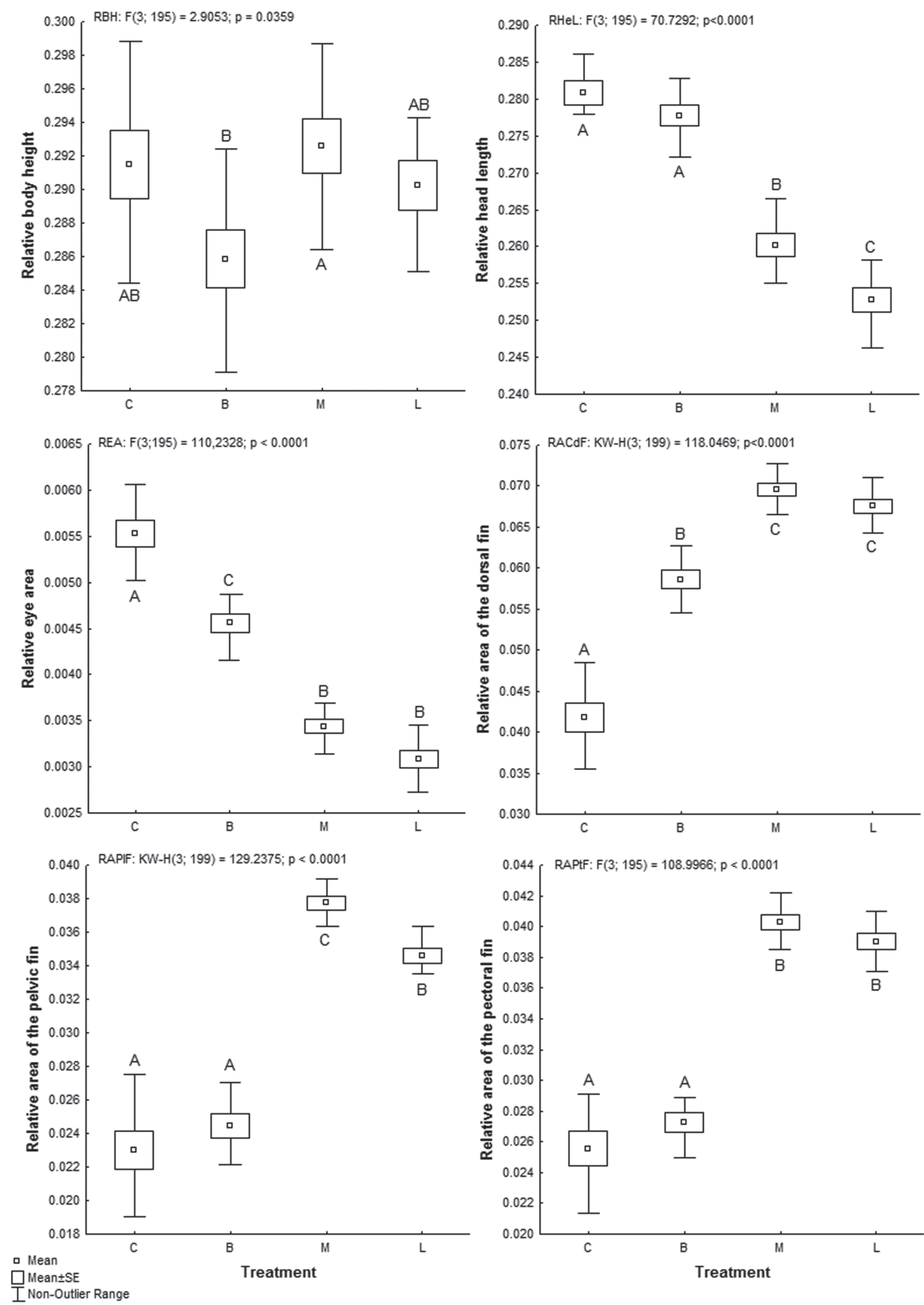

Fig. 6. Most important ecomorphological attributes for Brycon orbignyanus in the morphological differentiation among treatments, according to the ANOVA and the DCA, concomitantly. Treatments with a different letter above their ranges differed significantly. 


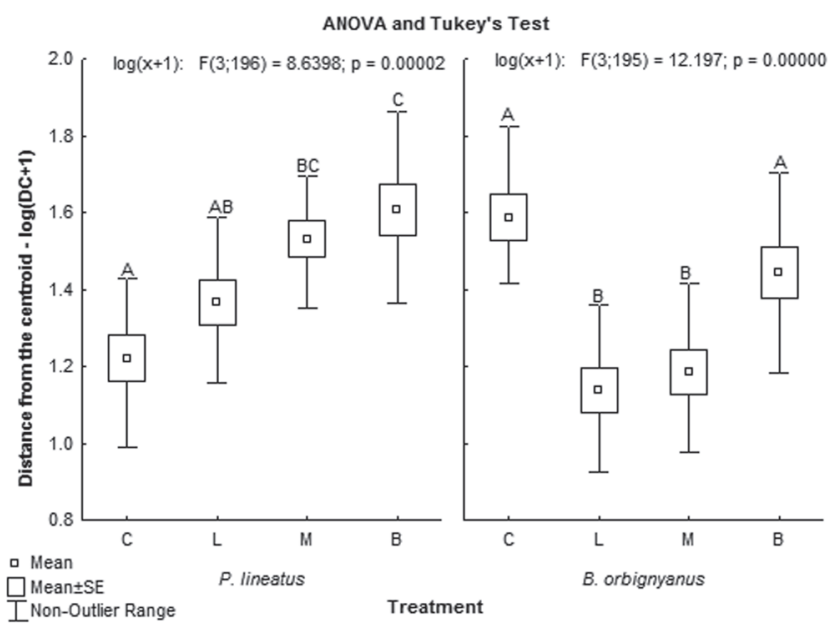

Fig. 7. The log of the distance from the centroid plus 1 [ $\log$ $(\mathrm{DC}+1)]$ for Prochilodus lineatus and Brycon orbignyanus. The ANOVA was significant for both species $(\mathrm{p}<0.0001)$, demonstrating significant differences among the treatments. The results of the Tukey tests, specifying which DCs were different from each other, are demonstrated by the letters A, B, and C. Different letters indicate significant differences among the treatments.

heterogeneous, which allowed the coexistence of morphologies suitable to one and/or the other structure.

Regarding physiological aspects, for $P$. lineatus, treatment $M$ was the only one that reduced the condition factor significantly. As all tanks received the same amount food at the same rate, the cause of the decrease in the balance between weight and length may be credited to the presence of artificial macrophytes, which apparently hampered the development of P. lineatus. In fact, during the experiment, we observed the accumulation of food between the plastic strips of macrophytes, which became tangled with the movement of water and fish passage, accumulating food fragments and making them inaccessible to individuals, which may have generated a food deficit. Finally, it is important to consider that logs do not represent an obstacle for feeding, and likely increase food availability through biofilm.

For $B$. orbignyanus, treatment $\mathrm{L}$ was the one that most reduced the condition factor, followed by treatment $\mathrm{M}$ and eventually treatment $B$, though the latter did not differ from the control. The fact that treatments $\mathrm{L}$ and $\mathrm{M}$ reduced the condition factor of $B$. orbignyanus does not necessarily indicate that the enrichment hindered their development. On the contrary, when analyzing the data on standard length, it is noticeable that the treatments $\mathrm{L}$ and $\mathrm{M}$ contained the fish of greater lengths, that is, they were those that grew the most. This result differs from that found for trout by Berejikian et al. (2001), who found no differences in the growth of fish reared in conventional tanks and tanks enriched with submerged structures.

Whether by increasing the structural complexity or whether by increasing the variety and quantity of food provided by the biofilm of structures, the results found here demonstrate that the enrichment of fish-farming tanks, during the development phase of fish, can be an effective tool for inducing morphological differentiation through phenotypic plasticity. For $P$. lineatus, enrichment through submerged logs and aquatic plants can be proposed as a way to increase the morphological variability of cultured populations. For $B$. orbignyanus, a higher morphological variability could be generated by the simultaneous maintenance of different hatchery forms (tanks with different manners of structuring). However, further studies should be conducted to improve the enrichment techniques, searching for the most appropriate structures for each species that do not have a negative influence on the development of the fishes and that make them as morphologically varied as those in the wild, to increase the probability of their survival after their release into the natural environment.

\section{Acknowledgments}

We are most grateful to Companhia Energética de Minas Gerais (CEMIG) for the support and to everyone of the fish station of Volta Grande for the essential help during the experiment, especially João de Magalhães Lopes, Alessandra Bedore and Sônia Maria Ramos.

\section{Literature Cited}

Agostinho, A. A., L. C. Gomes \& F. M. Pelicice. 2007. Ecologia e manejo de recursos pesqueiros em reservatórios do Brasil. Maringá, Universidade Estadual de Maringá.

Agostinho, A. A. \& H. F. Júlio-Junior. 1999. Peixes da bacia do Alto Paraná. Pp. 374-400. In: Lowe-McConnell, R. H. Estudos ecológicos de comunidades de peixes tropicais. São Paulo, Universidade de São Paulo.

Agostinho, A. A., E. Zaniboni-Filho \& F. C. T. Lima. 2008. Brycon orbignyanus (Valenciennes, 1850). Pp. 54-56. In: Machado, A. B. M., G. M. Drummond \& A. P. Paglia. Livro vermelho da fauna brasileira ameaçada de extinção. Brasília, Ministério do Meio Ambiente.

Batzina, A. \& N. Karakatsouli. 2012. The presence of substrate as a means of environmental enrichment in intensively reared gilthead seabream Sparus aurata: Growth and behavioral effects. Aquaculture, 370-371: 54-60.

Belk, M. C., L. J. Benson, J. Rasmussen \& S. L. Peck. 2008. Hatchery-induced morphological variation in an endangered fish: a challenge for hatchery-based recovery efforts. Canadian Journal of Fisheries and Aquatic Sciences, 65: 401-408.

Berejikian, B. A., E. P. Tezak, S. C. Riley \& A. L. Larae. 2001. Competitive ability and social behavior of juvenile steelhead reared in enriched and conventional hatchery tanks and a stream environment. Journal of Fish Biology, 59: 1600-1613.

Borba, M. R., D. M. Fracalossi \& L. E. Pezzato. 2006. Dietary energy requirement of piracanjuba fingerlings, Brycon orbignyanus, and relative utilization of dietary carbohydrate and lipid. Aquaculture Nutrition, 12: 183-191.

Braithwaite, V.A. \& A. G. V. Salvanes. 2005. Environmental variability in the early rearing environment generates behaviourally flexible cod: implications for rehabilitating wild populations. Proceedings of the Royal Society Biology, 272: 1107-1113. 
Breda, L., E. F. Oliveira \& E. Goulart. 2005. Ecomorfologia de locomoção de peixes com enfoque para espécies neotropicais. Acta Scientarium Biological Sciences, 27: 371-381.

Brown, C., T. Davidson \& K. Laland. 2003. Environmental enrichment and prior experience of live prey improve foraging behaviour in hatchery-reared Atlantic salmon. Journal of Fish Biology, 63: 187-196.

Brown, C. \& K. Laland. 2001. Social learning and life skills training for hatchery reared fish. Journal of Fish Biology, 59: 471-493.

Fleming, I. A., N. B. Jonsson \& M. R. Gross. 1994. Phenotypic divergence of sea-ranched, farmed, and wild salmon. Canadian Journal of Fisheries and Aquatic Sciences, 51: 2808-2824.

Garduño-Paz, M. V., S. Couderc \& C. E. Adams. 2010. Habitat complexity modulates phenotype expression through developmental plasticity in the threespine stickleback. Biological Journal of the Linnean Society, 100: 407-413.

Gatz Junior, A. J. 1979. Ecological morphology of freshwater stream fishes. Tulanne Studies in Zoology Botany, 21: 91-124.

Gosline, W. A. 1971. Functional morphology and classification of teleostean fishes. Honolulu, University of Hawaii.

Hahn, N. S., R. Fugi \& I. F. Andrian. 2004. Trophic ecology of the fish assemblages. Pp. 247-269. In: Thomaz, S. M., A. A. Agostinho \& N. S. Hahn (Orgs.). The Upper Paraná River and its Floodplain: physical aspects, ecology and conservation. Leiden, Backhuys Publishers.

Hard, J. J., B. A. Berejikian, E. P. Tezak, S. Schroder, C. M. Knudsen \& L. T. Parker. 2000. Evidence for morphometric differentiation of wild and captively reared adult coho salmon: a geometric analysis. Environmental Biology of Fishes, 58: 61-73.

Hora, S. L. 1930. Ecology, bionomics and evolution of the torrential fauna, with special reference to the organs of attachment. Philosophical Transactions of the Royal Society of London, 28: 171-282.

Lee, J. S. F. \& B. A. Berejikian. 2008. Effects of the rearing environment on average behaviour and behavioural variation in steelhead. Journal of Fish Biology, 72: 1736-1749.

Lopera-Barrero, N. M. 2009. Conservation of Brycon orbignyanus natural populations and stocks for their reproductive, genetic, environmental sustainability: A model for species threatened with extinction. Ciencia e Investigación Agraria, 36: 191-208.

Maciel, C. M. R. R., E. A. T. Lanna, A. Jr. Maciel, J. L. Donzele, C. A. Neves \& E. Menin. 2010. Morphological and behavioral development of the piracanjuba larvae. Revista Brasileira de Zootecnia, 39: 961-970.

Maynard, D. J., T. A. Flagg \& C. V. W. Mahnken. 1994. A Review of Seminatural Culture Strategies for Enhancing the Postrelease Survival of Anadromous Salmonids. Seattle, National Marine Fisheries Service.

Newberry, R. C. 1995. Environmental enrichment: Increasing the biological relevance of captive environments. Applied Animal Behaviour Science, 44: 229-243.
Pakkasmaa, S., E. Ranta \& Piironen. 1998. A morphometric study on four land-locked salmonid species. Annales Zoologici Fennici, 35: 131-140.

Pouilly, M., F. Lino, J. G. Bretenoux \& C. Rosales. 2003. Dietary morphological relationships in a fish assemblage of the Bolivian Amazonian floodplain. Journal of Fish Biology, 62: 1137-1158.

Rand, P. S., B. Berejikian, T. N. Pearsons \& D. L. G. Noakes. 2012. Ecological interactions between wild and hatchery salmonids: an introduction to the special issue. Environmental Biology of Fishes, 94: 1-6.

Reynalte-Tataje, D., R. K. Luz, S. Meurer, E. Zaniboni-Filho \& A. P. O. Nuñer. 2002. Influência do fotoperíodo no crescimento e sobrevivência de pós-larvas de piracanjuba Brycon orbignyanus (Valenciennes, 1849) (Osteichthyes, Characidae). Acta Scientiarum, 24: 439-443.

Roberts, L. J., J. Taylor \& C. Garcia de Leaniz. 2011. Environmental enrichment reduces maladaptive risk-taking behavior in salmon reared for conservation. Biological Conservation, 144: 19721979.

Salvanes, A. \& V. Braithwaite. 2006. The need to understand the behaviour of fish reared for mariculture or restocking. ICES Journal of Marine Science, 63: 346-354.

Swain, D. P., B. E. Riddell \& C. B. Murray. 1991. Morphological differences between hatchery and wild populations of coho salmon (Oncorhynchus kisutch): environmental versus genetic origin. Canadian Journal of Fisheries and Aquatic Sciences, 48: 1783-1791.

Taylor, E. B. 1986. Differences in morphology between wild and hatchery populations of juvenile Coho Salmon. The Progressive Fish-Culturist, 48: 171-176.

Vaz, M. M., V. C. Torquato \& N. D. C. Barbosa. 2000. Guia ilustrado de peixes da bacia do Rio Grande. Belo Horizonte, CEMIG/ CETEC.

Viveiros, A. T. M., L. H. Órfão, A. N. Maria \& I. B. Allaman. 2009. A simple, inexpensive and successful freezing method for Curimba Prochilodus lineatus (Characiformes) semen. Animal Reproduction Science, 112: 293-300.

Watson, D. J. \& E. Balon. 1984. Ecomorphological analysis of taxocenes in rainforest streams of northern Borneo. Journal of Fish Biology, 25: 371-384.

Winemiller, K. O. 1991. Ecomorphological diversification in lowland freshwater fish assemblages from five biotic regions. Ecological Monographs, 61: 343-365.

Submitted November 20, 2013 Accepted May September, 2014 by Lilian Casatti Published December 27, 2014 